\title{
HUBUNGAN LINGKUNGAN FISIK RUMAH DENGAN KEJADIAN TB PARU DI WILAYAH KERJA PUSKESMAS MIRIT KABUPATEN KEBUMEN TAHUN 2016
}

\author{
Dewi Prihartanti*), Agus Subagiyo**), Suparmin ${ }^{* * *}$ \\ Jurusan Kesehatan Lingkungan, Politeknik Kesehatan Kemenkes Semarang, \\ Jl.Raya Baturaden KM 12 Purwokerto, Indonesia
}

\begin{abstract}
Abstrak
Tuberculosis adalah penyakit menular langsung yang disebabkan oleh kuman TB (Mycobacterium tuberculosis). Rumah yang tidak memenuhi syarat kesehatan merupakan salah satu faktor resiko penyakit TB Paru. Penelitian ini bertujuan untuk mengetahui hubungan antara lingkungan fisik rumah dengan kejadian TB Paru di wilayah kerja Puskesmas Mirit Kebumen. Penelitian ini menggunakan metode survei analitik dengan rancangan kasus kontrol. Populasi dalam penelitian ini adalah penderita TB Paru dan bukan penderita TB Paru yang berjumlah 40 orang. Tehnik pengambilan sampel menggunakan total sampling. Hasil analisis bivariat menunjukkan bahwa ada hubungan signifikan antara kejadian TB Paru dengan luas ventilasi ( $p=0,004 ;$ OR $=7,429)$, pencahayaan alami $(p=0,004 ;$ OR $=7,000)$, suhu $(p=$ 0,003; $O R=8,500)$. Disarankan agar setiap akan merenovasi atau membangun rumah agar memperhatikan aspek sanitasi rumah sehat dan meningkatkan perilaku hidup bersih dan sehat.
\end{abstract}

Kata kunci: lingkungan fisik rumah, TB Paru

\begin{abstract}
Tuberculosis is a direct contagion that caused by Mycrobacterium tuberculosis. Houses without health requirement are one of risk factor of pulmonary tuberculosis. This study determines relation between house physical environment with the event of pulmonary tuberculosis cases in work area of Mirit health center, Kebumen district in 2016. This study is a observational analytic case-control study design. The population were patients with pulmonary TB and non pulmonary TB, amounting to 40 people. Sampling technique applied total sampling. Bivariat analysis showed that there is a relationship between the incidence of pulmonary $T B$ and ventilation ( $p$ value $=0,004$ and $O R=7,429$ ), natural lighting ( $p$ value $=0,004$ and $O R=7,000)$, temperature ( $p$ value $=0,003$ and $O R=8,500)$. Advised everyone who will renovate or build the house should consider aspects of home sanitation and follow the healthy life behaviour.
\end{abstract}

Keywords: house physical environment, Pulmonary TB

\footnotetext{
${ }^{*}$ E-mail: prihartanti_dewi@yahoo.com

${ }^{* * *}$ E-mail: agusgiyo@yahoo.co.id

${ }^{* * *}$ E-mail: pakparmin@yahoo.com
}

\section{Pendahuluan}

Tuberkulosis (TB) paru merupakan penyakit menular langsung yang disebabkan oleh kuman TB (Mycobacterium tuberculosis), suatu bakteri berbentuk batang yang tahan asam terhadap pewarnaan (Depkes R.I, 2007).

Menurut Depkes RI (2008), menyatakan bahwa penyakit TB Paru merupakan penyebab kematian nomor 3 (tiga) setelah kardiovaskuler dan penyakit saluran pernafasan pada semua kelompok usia dan nomor 1 dari golongan penyakit infeksi. Diperkirakan ada sekitar 9 (sembilan) juta pasien TB Paru baru dan 3 (tiga) juta kematian akibat TB Paru di dunia, terjadi di negara- 
negara berkembang. Sekitar $75 \%$ pasien TB Paru adalah kelompok usia paling produktif secara ekonomis, yaitu usia 15-50 tahun.

Profil kesehatan Indonesia tahun 2014 menempatkan Jawa Tengah pada urutan ke tiga untuk penemuan kasus TB Paru BTA positi yaitu sebesar 16.079 kasus. Data dari Dinas Kesehatan Kabupaten Kebumen tahun 2014 menunjukkan bahwa penemuan kasus TB Paru BTA positif berjumlah 673 penderita. Data profil Puskesmas Mirit tahun 2014 menunjukkan bahwa penderita TB Paru BTA positif di kecamatan Mirit berjumlah 26 kasus. Jumlah kasus TB Paru BTA positif tahun 2015 berjumlah 18 kasus, dan sampai dengan pertengahan bulan Januari 2016 ditemukan kasus baru TB Paru BTA positif sejumlah 3 kasus. Hasil pemeriksaan rumah sehat di Kecamatan Mirit pada tahun 2015 menunjukkan dari 11.690 rumah yang diperiksa, terdapat $8.568 \quad(73,29 \%)$ rumah yang memenuhi syarat kesehatan, yang berati masih di bawah target Kementerian Kesehatan yaitu lebih dari $80 \%$ penduduk tinggal dalam rumah sehat.

Beberapa faktor yang erat hubungannya dengan terjadinya infeksi basil tuberkulosis adalah adanya sumber penularan, tingkat paparan, virulensi, daya tahan tubuh yang erat kaitannya dengan faktor genetik, faktor faali, jenis kelamin, usia, status gizi, perumahan dan jenis pekerjaan (Amir, Muhammad dan Assegaf H.,1989). Kesehatan perumahan merupakan lingkungan fisik, kimia, dan biologik di lingkungan rumah dan perumahan sehingga memungkinkan penghuni atau masyarakat memperoleh derajat kesehatan yang optimal.

Hasil penelitian Suwaryo (2010) didapatkan bahwa ada hubungan yang signifikan antara jenis lantai, luas ventilasi, pencahayaan alami dan kepadatan hunia rumah dengan kejadian TB Paru.

Hasil penelitian Debiyanto (2015) menunjukkan bahwa ada hubungan yang signifikan antara kepadatan hunian, luas ventilasi dan pencahayaan alami dengan kejadian TB Paru. Tidak ada hubungan antara kelembaban dengan kejadian TB Paru.

\section{Bahan dan Metode}

Jenis penelitian adalah survei analitik, dengan rancangan case control untuk membandingkan kelompok kasus dan kelompok kontrol berdasarkan status paparannya. Lokasi penelitian ini adalah di wilayah kerja Puskesmas Mirit Kabupaten Kebumen yang dilaksanakan pada bulan Mei-Juli 2016.

Populasi pada penelitian ini adalah seluruh penderita yang dinyatakan tuberkulosis paru BTA positif yang datang ke Puskesmas dan bertempat tinggal di wilayah Kecamatan Mirit dan tercatat di register TB Puskesmas Miri periode Januari 2015 - Januari 2016 sebanayk 20 orang. Tehnik sampling yang digunakan dalam penelitian ini adalah dengan mengunakan metode
Total Sampling, dengan perbandingan antara kasus : kontrol $=1: 1$, dimana sampel terdiri dari 20 responden sebagai kelompok kasus dan 20 responden sebagai kelompok kontrol, sehingga jumlah sampel secara keseluruhan adalah 40 sampel. Pengumpulan data pada penelitian dilakukan dengan menggunakan check list observasi. Observasi dilakukan terhadap variabel lingkungan fisik rumah yang merupakan faktor resiko kejadian TB Paru.

Analisis data yang digunakan adalah analisis univariat dan analisis bivariat. Analisis univariat dilakukan untuk mengetahui distribusi frekuensi dan presentase setiap variabel yang kemudian disajikan dalam bentuk tabel dan diinterpretasikan. Sedangkan analisis bivariat dilakukan terhadap dua variabel yang iduga berhubungan atau menggunakan uji statistik ChiSquare $\left(\mathrm{X}^{2}\right)$ dengan derajat kepercayaan 95\% $(\alpha=0,05)$. Hubungan dikatakan bermakna jika $\mathrm{p}<0,05$ dan meihat nilai Odds Ratio (OR) untuk memperkirakan risiko masing-masing variabel yang diteliti.

\section{Hasil dan Pembahasan \\ A. Karakteristik Responden}

a. Umur

Proporsi umur responden pada kelompok kasus paling banyak adalah $31-45$ tahun yaitu 8 orang (40\%). Pada kelompok kontrol, umur responden paling banyak juga entang umur 3145 tahun yaitu 6 orang (30\%).

b. Jenis Kelamin

Distribusi responden berdasarkan jenis kelamin pada kelompok kasus maupun kontrol, responden laki-laki lebih banyak, yaitu 26 orang $(65 \%)$, dibandingkan dengan responden perempuan, yaitu sejumlah 14 orang (35\%).

c. Status Perkawinan

Distribusi responden berdasarkan status perkawinan pada kelompok kasus maupun kontrol, responden dengan status kawin lebih banyak, yaitu 32 orang $(80 \%)$, dibandingkan responden dengan status tidak kawin, yaitu sejumlah 8 orang $(20 \%)$.

d. Tingkat pendidikan

Proporsi tingkat pendidikan responden kelompok kasus yang paling banyak adalah tamat SMA/sederajat yaitu 7 orang (35\%), pada kelompok kontrol tingkat pendidikan yang paling banyak adalah tamat SD yaitu 8 orang $(40 \%)$.

e. Jenis Pekerjaan

Proporsi jenis pekerjaan responden kasus paling banyak $50 \%$ pekerjaan sebagai petani 
pemilik dan memiliki pekerjaan dalam kategori lain-lain (IRT,sopir). Pada kelompok kontrol $30 \%$ pekerjaan sebagai petani pemilik.

f. Perilaku

Berdasarkan perilaku responden, proporsi perilaku tidak baik responden pada kelompok kasus $15 \%$ lebih kecil dibanding perilaku tidak baik pada kelompok kontrol yaitu $60 \%$.

g. Kontak penderita

Berdasarkan kontak penderita, responden kasus yang pernah kontak dengan penderita yaitu
$25 \%$, dan responden kontrol adalah $0 \%$ yang pernah kontak dengan penderita

\section{B. Analisis Univariat}

Tabel 1. Distribusi Frekuensi Lingkungan Fisik Rumah

\begin{tabular}{|c|c|c|c|c|c|c|c|c|}
\hline \multirow[t]{2}{*}{ No. } & \multirow[t]{2}{*}{ Variabel } & \multirow[t]{2}{*}{ Kategori } & \multicolumn{2}{|c|}{ Kasus } & \multicolumn{2}{|c|}{ Kontrol } & \multicolumn{2}{|c|}{ Jumlah } \\
\hline & & & Jumlah & $\%$ & Jumlah & $\%$ & Jumlah & $\%$ \\
\hline \multirow[t]{2}{*}{1.} & Jenis lantai & Tidak kedap air & 7 & 35 & 2 & 10 & 9 & 22,5 \\
\hline & & Kedap air & 13 & 65 & 18 & 90 & 31 & 77,5 \\
\hline \multirow[t]{2}{*}{2.} & Luas ventilasi & $<10 \%$ luas lantai & 16 & 80 & 7 & 35 & 23 & 57,5 \\
\hline & & $\geq 10 \%$ luas lantai & 4 & 20 & 13 & 65 & 17 & 42,5 \\
\hline \multirow[t]{2}{*}{3.} & Pencahayaan alami & $<60 \operatorname{lux}$ & 14 & 70 & 5 & 25 & 19 & 47,5 \\
\hline & & $\geq 60$ lux & 6 & 30 & 15 & 75 & 21 & 52,5 \\
\hline \multirow[t]{2}{*}{4.} & Kepadatan hunian & $<10 \mathrm{~m}^{2} /$ orang & 3 & 15 & 3 & 15 & 6 & 15 \\
\hline & & $\leq 10 \mathrm{~m}^{2} /$ orang & 17 & 85 & 17 & 85 & 34 & 85 \\
\hline \multirow[t]{2}{*}{5.} & Kelembaban udara & $<40 \%$ atau $>70 \%$ & 16 & 80 & 12 & 60 & 28 & 70 \\
\hline & & $40 \%-70 \%$ & 4 & 20 & 8 & 40 & 12 & 30 \\
\hline \multirow[t]{2}{*}{6.} & Suhu & $<18^{\circ} \mathrm{C}$ atau $>30^{\circ} \mathrm{C}$ & 12 & 60 & 3 & 15 & 15 & 37,5 \\
\hline & & $18^{\circ} \mathrm{C}-30^{\circ} \mathrm{C}$ & 8 & 40 & 17 & 85 & 25 & 62,5 \\
\hline
\end{tabular}

Jenis lantai rumah responden yang tidak kedap air pada kelompok kasus sejumlah 35\% lebih banyak dibanding dengan kelompok kasus sejumlah $10 \%$.

Luas ventilasi yang tidak memenuhi syarat ( $<10 \%$ luas lantai) pada kasus $80 \%$, sedangkan pada kontrol yang tidak memenuhi syarat yaitu $35 \%$.

Proporsi pencahayaan alami pada kelompok kasus yang tidak memenuhi syarat $70 \%$ dan yang memenuhi syarat 30\%. Pencahayaan alami pada kelompok kontrol yang tidak memenuhi syarat $25 \%$ dan yang memenuhi syarat yaitu $75 \%$.

Kepadatan hunian yang tidak memenuhi syarat pada kelompok kasus maupun kontrol adalah sama yaitu $15 \%$ dan yang memenuhi syarat yaitu $85 \%$.

Kelembaban udara pada kelompok kasus yang tidak memnuhi syarat adalah $80 \%$ sedangkan yang memenuhi syarat yaitu $20 \%$. Kelembaban udara pada kelompok kontrol yang tidak memenuhi syarat yaitu $60 \%$ dan yang tidak memenuhi syarat adalah $40 \%$.

Suhu pada kelompok kasus yang tidak memenuhi syarat yaitu $60 \%$ dan yang memenuhi syarat adalah $40 \%$, sedangkan pada kelompok kontrol suhu yang tidak memenuhi syarat yaitu $15 \%$ dan yang memenuhi syarat adalah $85 \%$. 



\section{Analisis Bivariat}

Tabel 2. Hubungan Lingkungan Fisik Rumah dengan Kejadian TB Paru di Wilayah Kerja Puskesmas Mirit Tahun 2016

\begin{tabular}{llcccl}
\hline No & \multicolumn{1}{c}{ Variabel } & OR & \multicolumn{1}{c}{$95 \%$ CI } & Nilai P & \multicolumn{1}{c}{ Ket } \\
\hline 1. & Jenis lantai & 4,846 & $0,863-27,221$ & 0,127 & Tidak signifikan \\
2. & Luas ventilasi & 7,429 & $1,778-31,040$ & 0,004 & Signifikan \\
3. & Pencahayaan alami & 7,000 & $1,739-28,174$ & 0,004 & Signifikan \\
4. & Kepadatan hunian & 1,000 & $0,176-5,673$ & 1,000 & Tidak signifikan \\
5. & Kelembaban & 2,667 & $0,648-10,972$ & 0,168 & Tidak signifikan \\
6. & Suhu & 8,500 & $1,861-38,817$ & 0,003 & Signifikan \\
\hline
\end{tabular}

Hasil analisis statistik menggunakan uji chisquare pada variabel jenis lantai rumah menunjukkan tidak ada hubungan yang signifikan dengan kejadian TB Paru dimana nilai $\mathrm{P}=0,127$. Hal ini disebabkan karen prosentase rumah responden baik penderita TB Paru mupun bukan penderita TB Paru mempunyai jenis lantai yang kedap air lebih besar yaitu $77,5 \%$ lebih besar dari pada yang tidak kedap air yaitu $22,5 \%$. Hasil penelitian ini sesuai dengan penelitian Syafri (2015) yang menyatakan tidak terdapat hubungan yang bermakna antara jenis lantai rumah dengan kejadian TB Paru di wilayah kerja Puskesmas Ngemplak Boyolali, hasilnya adalah konstan, dimana jenis lantai rumah responden baik kasus maupun kontrol seluruhnya (100\%) sudah memenuhi standar rumah sehat sesuai dengan Kepmenkes No.829/Menkes/SK/VII/1999 tentang persyaratan kesehatan rumah.

Variabel luas ventilasi rumah dalam penelitian ini menunjukkan hubungan yang signifikan dengan kejadian TB Paru dengan nilai $\mathrm{P}=0,004$; $\mathrm{OR}=$ 7,429 . Dengan demikian orang yang tinggal di dalam rumah dengan luas ventilasi yang kurang mencukupi mempunyai resiko 7,429 kali lebih besar menderita TB Paru dibanding orang yang bertempat tinggal dalam rumah dengan luas ventilasi yang memenuhi syarat. Ventilasi yang tidak memenuhi syarat menyebabkan kurangnya sinar matahari yang masuk ke dalam rumah sehingga meningkatkan kelembaban di dalam rumah. Hasil penelitian ini sesuai dengan penelitian Fatimah (2008) yang menyatakan bahwa ada hubungan antara kejadian TB Paru dengan luas ventilasi $(\mathrm{p}=0,003 ; \mathrm{OR}=4,392)$.

Variabel pencahayaan alami diperoleh nilai $\mathrm{p}=$ 0,004 yang berarti ada hubungan yang bermakna antara pencahayaan alami dengan kejadian TB Paru. Odds ratio $7,000.95 \%$ CI $=1,739-28,174$ yang berarti rumah responden penderita BTA positif yang kondisi pencahayaan alami di dalam rumahnya $<60$ lux beresiko 7,000 kali tertular TB Paru dibandingkan rumah responden yang mempunyai pencahayaan yang baik. Banyak jenis bakteri yang dapat dimatikan jika bakteri tersebut mendapatkan sinar matahari secara langsung, demikian juga kuman tuberkulosis dapat mati karena cahaya sinar ultraviolet dari sinar matahari yang masuk secara langsung ke dalam ruangan. Diutamakan sinar matahari pagi karena cahaya matahari pagi mengandung sinar ultraviolet yang dapat membunuh kuman (Depkes RI, 1994). Penelitian ini sejalan dengan penelitian Wahyuni (2012) yang mengungkapkan terdapat hubungan antara pencahayaan alami dengan kejadian TB Paru $(\mathrm{p}=0,010)$.

Tidak ada hubungan antara kepadatan hunian dengan kejadian TB Paru, nilai $\mathrm{p}=1,000$. Hal ini dikarenakan hasil observasi kepadatan hunian rumah responden memenuhi syarat kesehatan, artinya luas rumah sebanding dengan jumlah penghuninya sehingga tidak menyebabkan overcrowded, dan kemungkinan terinfeksi tuberkulosis kecil. Hasil penelitian ini tidak sesuai dengan penelitian Wirasetya (2015) yang menyatakan ada hubungan antara kepadatan hunian dengan kejadian TB Paru ( $\mathrm{p}=0,016$; $\mathrm{OR}=9)$. Perbedaan antara penelitian ini dengan penelitian Wirasetya dapat dilihat dari lokasi penelitian Wirasetya yang berada di kelurahan Tnjung Priok Jakarta Utara sehingga kepadatan hunian rumahnya cukup padat tidak seperti penelitian yang dilakukan di daerah desa (Kecamatan Mirit Kabupaten Kebumen) dengan kondisi rumah yang luas dan tidak padat penghuninya.

Tidak ada hubungan bermakna antara kelembaban udara dengan kejadian TB Paru dengan nilai $\mathrm{p}=0,168$. Kelembaban yang tidak 
memenuhi syarat merupakan faktor resiko yang berhubungan dengan kejadian TB Paru. Namun dalam penelitian ini tidak terdapat perbedaan kelembaban udara antara kelompok kasus dan kontrol. Penelitian ini dilakukan pada bulan MeiJuli dimana curah hujan masih cukup tinggi sehingga kelembaban udara dalam rumah juga tinggi. Hasil penelitian ini sesuai dengan penelitian Ayunah (2008) yang menyatakan bahwa tidak ada hubungan yang signifikan antara kelembaban rumah dengan kejadian TB Paru.

Variabel suhu diperoleh nilai $\mathrm{p}=0,003$, sehingga $\mathrm{p}<0,05$, yang berarti ada hubungan yang signifikan antara suhu dengan kejadian TB Paru. Nilai OR $=8,500$ yang berarti responden dengan suhu yang tidak memenuhi syarat kesehatan mempunyai kemungkinan menderita TB Paru 8,500 kali lebih besar dibanding responden dengan suhu yang memenuhi syarat kesehatan. Keberadaan suhu sangat berperan sekali pada pertumbuhan basil Mycobacterium tuberculosis, dimana laju pertumbuhan basil tersebut ditentukan berdasarkan suhu udara yang berada di sekitarnya. Kondisi ini sangat terkait dengan sirkulasi udara di dalam rumah yang berhubungan langsung dengan udara luar rumah dan tidak memenuhi syarat kesehatan akibat dari luas ventilasi yang kurang dari $10 \%$ luas lantai. Adanya sirkulasi udara yang baik diharapkan dapat meminimalisasi penularan TB Paru dalam rumah. Penelitian ini sesuai dengan penelitian Batti (2013) yang menyatakan bahwa terdapat hubungan antara suhu ruangan dengan kejadian penyakit TB Paru, dimana $\mathrm{p}=0,000$ dan $\mathrm{OR}=9,117$ dengan $95 \% \mathrm{CI}=3,66<\mathrm{OR}<22,65$.

\section{Kesimpulan}

Berdasarkan tujuan dan hasil penelitian tentang Hubungan Lingkungan Fisik Rumah dengan Kejadian TB Paru di Wilayah Kerja Puskesmas Mirit Kabupaten Kebumen Tahun 2016, dapat disimpulkan beberapa hal sebagai berikut :

a. Lingkungan fisik rumah penderita TB Paru yang memenuhi persyaratan kesehatan : jenis lantai rumah 77,5\%; luas ventilasi 42,5\%; pencahayaan alami 52,5\%; kepadatan hunian $85 \%$; kelembaban udara rumah $30 \%$; suhu ruangan rumah $62,5 \%$.

b. Tidak ada hubungan antara jenis lantai dengan kejadian TB Paru nilai $\mathrm{p}=0,127$.

c. Ada hubungan antara luas ventilasi rumah dengan kejadian TB Paru nilai $\mathrm{p}=0,004$; OR $=7,429$

d. Ada hubungan yang signifikan antara pencahayaan alami rumah dengan kejadian TB Paru nilai $\mathrm{p}=0,004 ; \mathrm{OR}=7,000$ e. Tidak ada hubungan antara kepadatan hunian dengan kejadian TB Paru nilai $\mathrm{p}=1,000$

f. Tidak ada hubungan antara kelembaban udara dengan kejadian TB Paru nilai $\mathrm{p}=$ 0,168

g. Ada hubungan yang signifikan antara suhu ruangan rumah dengan kejadian TB Paru

\section{Daftar Pustaka}

Amir, Muhamad, Alsagaff H., 1989, Pengantar Ilmu Penyakit Paru, Surabaya : Airlangga University Press.

Arikunto, S., 2002, Prosedur Penelitian Suatu Pendekatan Praktek, Jakarta : Rineka Cipta

Azwar A., 1995, Pengantar Ilmu Kesehatan Lingkungan, Mutiara, Jakarta

Ayunah, Y., 2008, Hubungan Kualitas Lingkungan Fisik Rumah dengan Kejadian Tuberkulosis Paru BTA Positif di Kecamatan Cilandak Kota Administratif Jakarta Selatan Tahun 2008, [Skripsi Ilmiah], Depok : Fakultas Kesehatan Masyarakat Universitas Indonesia

Batti Hera T.S, 2013, Analisis Hubungan Antara Kondisi Ventilasi, Kepadatan Hunian, Kelembaban Udara dan Pencahayaan Alami Rumah dengan Kejadian Tuberkulosis Paru di Wilayah Puskesmas Wara Utara Kota Palopo, Jurnal Universitas Sam Ratulangi Manado, Diakses 05 Februari 2016

Departemen Kesehatan RI, 1994, Pengawasan Kualitas Kesehatan Lingkungan dan Pemukiman, Dirjen P2M \& PLP, Jakarta

Departemen Kesehatan RI, 1999, Keputusan Menteri Kesehatan RI No. 829/Menkes/SK/VII/1999, tentang Persyaratan Kesehatan Perumahan, Jakarta

Departemen Kesehatan RI, 2001, Pedoman Nasional Penanggulangan Tuberkulosis, Jakarta : Departemen Kesehatan RI

Departemen Kesehatan RI, 2002, Pedoman Nasional Penanggulangan Tuberkulosis, Jakarta : Departemen Kesehatan RI.

Departemen Kesehatan RI, 2008, Pedoman Nasional Penanggulangan Tuberkulosis, Jakarta : Departemen Kesehatan RI.

Dinas Kesehatan Propinsi Jawa Tengah, 2000, Faktor Risiko Yang Mempengaruhi Kesembuhan Pengobatan Penderita TB Paru di Jawa Tengah Tahun 2000, Laporan Hasil 
Penelitian (Tahap II), Dinkes Prop. Jawa Tengah, Semarang:4-6

Dinas Kesehatan Propinsi Jawa Tengah, 2014, Profil Kesehatan Jawa Tengah, Semarang

Fatimah Siti, 2008, Faktor Kesehatan Lingkungan Rumah Yang Berhubungan Dengan Kejadian TB Paru di Kabupaten Cilacap (Kecamatan Sidareja, Cipari, Kedungreja, Patimuan, Gandrungmangu, Bantarsari) Tahun 2008, [Tesis Ilmiah], Semarang : Universitas Diponegoro

Girsang, Merryani, 2013, Mycobacterium Penyebab Penyakit Tuberculosis Serta Mengenal Sifat-sifat Pertumbuhannnya di Laboratorium, Jakarta : Pusat Biomedis dan Teknologi Dasar Kesehatan Badan Litbang Kesehatan Jakarta

Keman, Soedjajadi, 2005, Kesehatan Perumahan dan Lingkungan Pemukiman, Journal Kesehatan Lingkungan, Vol.2, No.1, Juli 2005

Misnadiarly, Simanjuntak, CH Pudjarwoto, 1990, Pengaruh Faktor Gizi dan Pemberian BCG terhadap Timbilnya Penyakit Tuberkulosis Paru, Cermin Dunia Kedokteran, 63: 20-24

Moha S.R, 2012, Pengaruh Kondisi Fisik Rumah Terhadap Kejadian TB Paru di Desa Pinolisian Kecamatan Pinolisian Kabupaten Bolaang Mangondow Selatan Tahun 2012, [Tesis Ilmiah], Gorontalo : Universitas Gorontalo

Nurhidayah Ikeu, 2007, Hubungan Antara Karakteristik Lingkungan Rumah Dengan Kejadian Tuberkulosis (TB) Pada Anak Di Kecamatan Paseh Kabupaten Sumedang, Fakultas Ilmu Keperawatan, Universitas Padjajaran, Bandung

Noor, Nur Nasry, 1994, Pengantar Epidemiologi Penyakit Menular, Jakarta : Rineka Cipta

Sanropie, Djasio, dkk, 1989, Pengawasan Penyehatan Pemukiman untuk Institusi Pendidikan Sanitasi Lingkungan, Jakarta: Pusdiknakes Depkes RI

Santjaka Aris, 2011, Statistik untuk Penelitian Kesehatan, Yogyakarta : Nuha Medika

Syafri A.K dan Purwoatmojo G, 2015, Hubungan Kondisi Fisik Rumah dengan Kejadian Tuberkulosis Paru Di Wilayah Kerja Puskesmas Ngempal Boyolali, Journal Ilmu Kesehatan Universitas Muhammaiyah Surakarta

Soemirat, Juli, 2000, Epidemiologi Lingkungan, Yogyakarta : Gajah Mada University Press
Suwaryo, 2010, Studi Hubungan Kondisi Fisik Rumah Terhadap Kejadian Penyakit TB. Paru di Wilayah Puskesmas Patikraja, Kabupaten Banyumas, Poltekkes Kemenkes Semarang, Jurusan Kesehatan Lingkungan Purwokerto

Supariasa, I Dewa N, 2002, Penilaian Status Gizi, Jakarta : ECG

Suyono, 1985, Pokok Bahasan Modul Perumahan dan Pemukiman, Jakarta : Pusdiknas

Wahyuni D.S, 2012, Hubungan Kondisi Fisik Rumah dan Karakteristik Individu dengan Kejadian Tuberkulosis Paru BTA Positif di Puskesmas Ciputat Kota Tangerang Selatan Tahun 2012, Jurnal Berkala Ilmiah Mahasiswa Kesehatan Masyarakat Indonesia, Vol. 1, No. 1, 1-6, 2012

Wirasetya, Debiyanto, 2015, Hubungan Sanitasi Rumah Dengan Kejadian TB Paru di Wilayah Kerja Puskesmas Kelurahan Tanjung Priok, Kecamatan Tanjung Priok, Jakarta Utara, Universitas Respati Indonesia, Fakultas Ilmu Kesehatan, Jakarta.

Widiyono, 2011, Penyakit Tropis : Epidemiologi, Penularan, Pencegahan dan Pemberantasanannya, Edisi Ke-2, Semarang : Erlangga 